\author{
Anna Haratyk \\ Zaktad Historii Edukacji \\ Instytut Pedagogiki \\ Uniwersytet Wroctawski
}

\title{
Mężczyzna w rodzinie górali huculskich
}

\begin{abstract}
Anna Haratyk, The Man in a Hutsul Highlanders' Family
Hutsuls as one of the ethnic groups living in the Carpathian mountains have created peculiar culture, distinct from other mountain societies and original in many aspects. The relationships in the socalled typical families were also very characteristic. Dominant role was played by a man. The oldest man in a family was responsible for relationships and rights in the family and for upbringing of children. Men's amoral behaviour, rooted in tradition, very often contributed to depravity and breakdown of marriages. Men often got married for fortune, were unfaithful to their wives and beat them. Such behaviour was treated in the Hutsul community as a husband's privilege and duty. The role of a man in the Hutsul family was significant but in many cases negative.
\end{abstract}

Keywords: Hutsuls, a man in a family, a traditional role of a man

Huculi, czyli górale Karpat Wschodnich, od wieków zamieszkiwali północno-wschodnie, lesiste stoki tego pasma górskiego. Od zachodu graniczyli z Bojkami, od północy i wschodu z Rusinami, a od południa oraz w Dolinie Suczawy, nad Mołdawą i Bystrzycą z Rumunami. W XIX i początkach XX w. spotkać ich można było zatem w dwóch krajach należących do Monarchii Austro-Węgierskiej - w Galicji i na Bukowinie ${ }^{1}$. W pierwszym z krajów zamieszkiwali 114 wsi, 4 przysiółki i 6 miasteczek, przy czym spośród tych drugich, zasiedlony wyłącznie przez Hucułów był tylko Mikuliczyn. W drugim z krajów zajmowali jedynie 32 wsie. Górali huculskich spotykano jeszcze w 9 wsiach na Węgrzech ${ }^{2}$. Zaznaczyć należy, że wsie były bardzo rozległe, poszczególne chaty, do których przylegały budynki gospodarcze, ogrody oraz grunty zwane carynkami, dzieliły od siebie najczęściej spore odległości. Zamożniejsi posiadali jeszcze pastwiska

\footnotetext{
1 Р. Ф. Кайндль, Гуцули, Відень 1894, s. 7.

2 S. Witwicki, Rys historyczny o Hucułach, Lwów 1863, s. 38-41.
} 
czyli połoniny, gdzie miejscem zamieszkania była dość prymitywna staja (szałas pasterski), w której Huculi nie starali się o żadne wygody ${ }^{3}$.

Na przestrzeni wieków stworzono wiele koncepcji próbujących wytłumaczyć pochodzenie Hucułów. R. Kajndl stwierdzał, że na te tereny mogła napływać ludność różnych grup etnicznych, ale największy wpływ na kształtowanie się Hucułów mieli Słowianie, żyjący u podnóża Karpat już od IV w. ${ }^{4}$ Zgodnie z powyższą teorią, Huculi bezsprzecznie byli Słowianami, o czym świadczyła ich mowa, zwyczaje, narodowe tradycje. Z drugiej strony nie brakowało im też i cech osobliwych, odróżniających Hucułów od reszty narodów słowiańskich (np. w słownictwie zachowało się sporo nazw obco brzmiących, m.in. rumuńskich). Wpływy różnych narodowości uwidoczniły się również w rumuńskim, węgierskim, polskim, ormiańskim, czy niemieckim brzmieniu nazwisk mieszkańców Huculszczyzny. Świadczyć to może o sporej liczbie przesiedleńców zamieszkujących, z różnych przyczyn, w trudno dostępnych górach. Najczęściej jednak podaje się, że pochodzą oni ze społeczności wołoskiej, a źródłosłów nazwy „Hucuł” wywodzi się z rumuńskiego „hoc - ul”, co oznaczało rozbójnika. Huculi długo nie określali się tą nazwą. Znacznie wcześniej tak nazywali ich sąsiedzi i być może mieli ku temu powody, biorąc pod uwagę działających w Karpatach zbójników - „opryszków”. Oni sami mówili o sobie „chrześcijanie”, ,górale”, ,werchowyńcy” lub „ruscy ludzie"5.

Na terenie Karpat Wschodnich do XIX w. zachodził podobny, jak na innych terenach proces transformacji rodziny. Wielka rodzina patriarchalna, rządząca się raczej prawami despotycznymi, stopniowo przekształciła się w rodzinę małą o prawach bardziej demokratycznych. Od najdawniejszych czasów mężczyzna - syn był spadkobiercą majątku po zmarłym ojcu. Córki miały szansę przejąć ojcowiznę tylko wówczas, gdy w rodzinie nie było syna. Tradycyjnie obowiązywał także zwyczaj nieingerowania przez mężczyzn w sprawy, prace i zajęcia gospodarcze należące do kobiet. Funkcjonował zatem tradycyjny podział ról, funkcji i czynności w rodzinie ${ }^{6}$.

Wielka rodzina złożona z dziadków, wujków, braci, sióstr, synów, synowych, córek, siostrzeńców, bratanków, wnuków oraz prawnuków, często żyła i gospodarowała w tzw. dworyszczu, w skład którego wchodziły ziemie z zagrodami, pastwiskami i polami uprawnymi (,dworyszcze” to zwykle 1 łan, czyli 16,8-25 ha) ${ }^{7}$. Nie zawsze jednak duża rodzina miała wspomniany obszar ziemi wyłącznie do swojej dyspozycji. Niejednokrotnie na powierzchni 1 łana gospodarowało kilka dużych rodzin.

J. Goszko, powołując się na badania W. Ochrymowycza i M. Kowalewskiego, biorąc pod uwagę terytorium Ukrainy, stwierdził, że charakterystyczna, wielka rodzina najdłużej zachowała się w Karpatach. Zwyczajowo dorośli synowie pozostawali i gospodarowali z ojcami na wspólnym gospodarstwie wraz z niezamężnymi siostrami i nieżonatymi

Ibidem, s. 42.

${ }^{4}$ Р. Ф. Кайндль, op. cit., s. 8.

5 Ibidem, s. 9.

${ }^{6}$ Ю. Гошко, Звичаєве право населення украӥнських Карпат та Прикарпаття XIV-XIX ст., Лвьвів 1999 , s. $227-228$.

${ }^{7}$ Ibidem, s. 228. 
braćmi. Wszyscy zamieszkiwali pod jednym dachem, razem jadali, gospodarowali i równo korzystali z tego co wypracowali. Całkowitą władzę nad członkami rodziny miał ojciec. Musieli mu być posłuszni nawet żonaci i mający już własne dzieci, synowie. Wszystkich członków ojciec traktował ciągle jak niepełnoletnie dzieci, zobowiązane do słuchania i dostosowywania się do podjętych przez niego decyzji. Społeczność huculska uważała za grzech sprzeciwianie się woli ojca. Natomiast gospodarz, który podzieliłby ziemię między synów uznawany był za nieudacznika ${ }^{8}$.

Nawet po śmierci ojca synowie gospodarowali wspólnie dopóki ich dzieci nie wyrosły, a obowiązek kierowania rodziną przechodził na najstarszego syna lub zięcia ${ }^{9}$. Prawo to trudno było jednak przestrzegać i nie zachowało się zbyt wiele dowodów na jego konsekwentne stosowanie w praktyce. Im bliżej XIX w. tym szybciej następował rozpad wielkich rodzin, a wspólne zamieszkiwanie czy gospodarowanie, często spotykane we wsiach huculskich, nie oznaczało wcale wielkiej wspólnoty rodzinnej. Zazwyczaj w takich rodzinach każdy żonaty syn miał swoją wyodrębnioną cząstkę gospodarstwa ${ }^{10}$. Wspólne życie kończyło się najczęściej z chwilą wybudowania przez synów własnych domów z zabudowaniami gospodarczymi, do których mogły się przenieść ich rodziny ze swoimi dobytkami.

Ukraińscy badacze J. Goszko i R. Czmełyk jednoznacznie stwierdzają, że na przestrzeni wieków XVI-XIX, na terenie Karpat Wschodnich dokonała się transformacja struktury rodziny. Stopniowo z rodziny wielkiej przekształciła się ona w małą. J. Goszko twierdzi wręcz, że na przełomie XVIII i XIX w. w Karpatach i na Podkarpaciu nie było już wielkich rodzin patriarchalnych ${ }^{11}$. R. Czmełyk, powołując się na innego ukraińskiego badacza stwierdza, że w tym czasie notowano przypadki wręcz wyjątkowe, gdy zamieszkujące pod jednym dachem małe rodziny miały osobne stoły i oddzielne grunty ${ }^{12}$. W drugiej połowie XIX i na początku XX w. małe wiejskie rodziny były najpopularniejsze na terenie całej Ukrainy. Do kształtowania się takiej struktury przyczyniała się dodatkowo industrializacja i urbanizacja społeczeństwa. Wraz z rozwojem uprzemysłowienia i transportu dołączało się do tego procesu geograficzne i ekonomiczne rozprzestrzenianie miejsc zamieszkania. Wśród przyczyn rozpadu dużych rodzin wymienić należy również pojawiające się rodzinne konflikty przy podziale pracy i zysków ${ }^{13}$.

W wieku XIX na Huculszczyźnie często spotkać można było małżeństwa mające sześcioro, siedmioro, a nawet dziewięcioro dzieci1 ${ }^{14}$. Liczba osób w rodzinie bywała zatem różna i zmienna, jednak zaobserwować można zdecydowaną przewagę rodzin patriarchalnych, w których głową był pradziadek, dziadek lub ojciec. Im przypadała władza

\footnotetext{
8 Ibidem, s. 230-231.

9 Р. Ф. Кайндль, op. cit., s. 36.

10 Ю. Гошко, Звичаєве право..., s. 231.

11 Ibidem, b/s, Р. Чмелик, Мала українська селянська сім'я другої половини ХІХ - початку XX cm. (Структура і функиіі), Львів 1999, s. 17.

12 Р. Чмелик, Мала українська селянська сім'я..., s. 33.

13 Ibidem, s. 135.

${ }^{14}$ Ю. Гошко, Звичаєве право..., s. 234.
} 
nad wszystkimi, ale w życiu codziennym mężczyzna kierujący rodziną był raczej daleki od despoty. Będąc jej głową, odpowiadał za panujące w niej stosunki, prawa i wychowanie rodzinne. Musiał jednak liczyć się z opinią wszystkich członków, w tym także żony, która miała w domu swoje prawa i starał się uwzględniać ich potrzeby ${ }^{15}$. Jak wspomniano, podział ról w rodzinie był wyraźny i zawsze przestrzegany. Na tej podstawie mąż nie wtrącał się w sprawy gospodarstwa domowego, które było domeną i obowiązkiem kobiet. Nieznajomość spraw związanych z prowadzeniem domu w żadnym wypadku nie wpływała negatywnie na autorytet głowy rodziny. Ojciec odpowiadał za wywiązywanie się rodziny ze wszystkich zobowiązań finansowych (podatki, czynsze, daniny itp.), za wychowanie dzieci (była to odpowiedzialność przed społecznością lokalną) i za bezpieczeństwo rodziny ${ }^{16}$. To, że mężczyzna ponosił publiczną odpowiedzialność za wychowanie dzieci, nie zwalniało kobiet z obowiązków wychowawczych.

Życie każdego przyszłego mężczyzny rozpoczynało się oczywiście w łonie matki. Kobieta, gdy tylko zorientowała się, że jest w ciąży, musiała bardzo uważać na swoje zachowanie. Decydowało ono bowiem o charakterze i przyszłości dziecka. Należało z drugiej strony również uważać, by nie obchodzić się z ciężarną zbyt surowo, ponieważ niechybnie czekało grubianina nieszczęście $\mathrm{w}$ gospodarstwie domowym ${ }^{17}$. Ciężarne kobiety do czasu rozwiązania wykonywały przypisane im czynności domowe. Z chwilą gdy rozpoczynał się poród, mąż udawał się spiesznie po najbliższą sąsiadkę, aby ta przyszła z pomocą rodzącej. Zważywszy na to, że domostwa huculskie były znacznie oddalone od siebie, kobiety nierzadko rodziły same, nie doczekawszy się pomocy ani od sąsiadki, która nie zdołała dojść na czas, ani od męża, który udał się po pomoc.

Analizując obyczaje huculskie towarzyszące dziecku w jego pierwszym okresie życia, główną rolę odgrywała tu matka i jej krewne bądź znajome. Ojciec zdecydowanie mniej angażował się w opiekę nad niemowlęciem. Potwierdzało to tradycyjny podział ról między kobietą, która zajmowała się dziećmi i domem, a mężczyzną pracującym w gospodarstwie domowym i poza nim (np. w lesie, na połoninie, przy spławie drewna). Nie wszystkie prace dało się wykonywać, zachowując ten tradycyjny podział ról. Wspólnym zajęciem były np. sianokosy, na które gazda zwoływał wszystkich. Zamiast zapłaty gospodarz urządzał dla pracujących przyjęcie $\mathrm{z}$ tańcami ${ }^{18}$. Cięższe prace wykonywali jednak zawsze mężczyźni. Do nich należało kopanie dołów i ustawianie „ostrywianyc” czyli ostrewek, na których suszono siano, a także przygotowanie pala na stóg siana (7-8 metrowy ciosany świerk). Mężczyźni zawsze znosili i podawali siano na stóg, a tam odbierała je grabiami i układała, stojąc na wierzchołku, kobieta ${ }^{19}$.

Zadaniem mężczyzn było również robienie przetworów nabiałowych z mleka pochodzącego od wypasanych na połoninach zwierząt domowych. Wyroby te sporządzał najczęściej watah w stai, czyli baca w szałasie (kolibie). Zdobienie wyrobów i przedmiotów

\footnotetext{
15 Ibidem, s. 236-237.

16 Ibidem, s. 237.

17 Р. Ф. Кайндль, Гуцули, s. 10.

${ }_{18}$ R. W. Harasymczuk, W. Tabor, Etnografia połonin huculskich, Lwów 1938, s. 14.

19 Ibidem, s. 15.
} 
użytku codziennego może świadczyć o wyczuciu i zdolnościach artystycznych przeciętnego Hucuła oraz o jego potrzebie otaczania się pięknymi przedmiotami. Artystyczne usposobienie i wrażliwość duszy przejawiała się również w tworzeniu wielu pieśni ludowych, opowiadających zarówno o życiu codziennym, zawodowym, pasterskim, jak o uczuciach. Tęskne pieśni o miłości powstawały zapewne pod wpływem rozstania na długi czas z najbliższą rodziną lub wybranką serca ${ }^{20}$. Okres lata część mężczyzn spędzała bowiem $\mathrm{z}$ dala od rodzin, wypasając zwierzęta na połoninach, wysoko w górach.

Przebywali tam od maja aż do jesiennych śniegów, czyli najczęściej do późnej jesieni. Będąc po kilka miesięcy w roku na połoninie, pasterze niestety mieli ograniczone możliwości w kwestii przestrzegania podstawowych zasad higieny. W celu zapobiegania pladze wszy i pcheł, gotowali bieliznę oraz koszule w mieszaninie masła i łoju, co pozwalało chodzić w tym samym ubraniu nawet przez okres całego wypasu. Im bliżej XX w. tym więcej uwagi do higieny osobistej zaczynali przywiązywać młodsi pasterze. Odrzucili oni tradycyjny sposób konserwowania odzieży na rzecz zmiany bielizny raz na tydzień lub dwa tygodnie. Nie korzystali wprawdzie z kąpieli, ale starali się często myć ręce, zwłaszcza po dojeniu. Wierzyli nawet, że jeśli pasterz po dojeniu z niemytymi rękoma zbliży się do ogniska, to zwierzętom spuchną wymiona i stracą one mleko. Dbali również o czystość drewnianych, miedzianych i żelaznych naczyń używanych na połoninach $^{21}$.

Życie przez kilka miesięcy wyłącznie w męskim towarzystwie nie wpływałoby zbyt pozytywnie na psychikę pasterzy. Pamiętając o tym, watah pozwalał na organizowanie, zwłaszcza w niedziele i święta, zabaw towarzyskich. Uczestniczyły w nich również dziewczęta i kobiety, przybywające na połoniny po bryndzę, masło lub by odwiedzić pasterzy i dowiedzieć się o stanie swoich zwierząt. Zabawy takie trwały zazwyczaj od świtu do zmierzchu. Natomiast w dzień powszedni życie towarzyskie skupiało się w stai, do której schodzili się pasterze na wspólne posiłki czy wieczorne spotkania. Siedząc przy ognisku nie ograniczali się oni wyłącznie do omawiania spraw związanych z wypasem, lecz opowiadali sobie legendy, baśnie, anegdoty ${ }^{22}$. Można więc stwierdzić, że staja była dla pasterzy i przebywających w niej gości miejscem edukacji kulturowej.

S. Witwicki ubolewał jednak nad izolacją mężczyzn i kobiet. Twierdził, że są oni zostawieni swej woli, przez co té̇ prowadza życie mniej więcej niemoralne $w$ czasie tych trzech miesięcy ${ }^{23}$. Z takiego stwierdzenia wysunąć można prosty wniosek, że kobiety na połoninach się pojawiały skoro mężczyźni prowadzili się w okresie wypasu niemoralnie. Z licznych przekazów wynika, że podobnie niemoralnie w tym okresie zachowywały się pozostające we wsiach kobiety. Stosunki panujące między mężczyznami a kobietami M. Orłowicz zaliczył do najoryginalniejszych cech wyróżniających Hucułów od innych grup etnicznych w Galicji, pisząc: Prawie każdy żonaty Hucuł ma kochanke (lubaska) i odwrotnie; stosunki erotyczne $w$ rodzinie nie należa do rzadkości. Najciekawszem jest

\footnotetext{
${ }^{20}$ Ibidem, s. 82.

21 Ibidem, s. 26-27.

22 Ibidem, s. 60.

23 S. Witwicki, Rys historyczny o Hucułach, Lwów 1863, s. 99.
} 
to, że pożycie takie wydaje się Hucułom rzecza najzupetniej normalna - a obowiazek wierności matżeńskiej nie istnieje dla nich wcale ${ }^{24}$.

Demoralizacja Hucułów, podkreślana przez wszystkich badaczy i podróżników opisujących mieszkańców Karpat Wschodnich, kształtowała się od przysłowiowej kolebki za sprawą negatywnego przykładu, jaki dawał dom rodzinny, będący podstawowym, a we wczesnym dzieciństwie jedynym środowiskiem wychowawczym. Swoboda, z jaką stykali się nastoletni chłopcy i dziewczęta w górach, wzmacniana popędami wieku dojrzewania sprawiała, że społeczność huculska wykształciła specyficzne i sobie tylko właściwe normy moralne, będące w rzeczywistości normami amoralnymi dla reszty ówczesnego społeczeństwa galicyjskiego. Akta sądowe, na które powoływał się R. Kaindl, pokazywały wiele niemoralnych wykroczeń kobiet zachęcających mężczyzn do stosunków pozamałżeńskich. Nie tylko kobiety zapisały swoimi wyczynami strony akt sądowych. Wielu przestępstw dopuszczali się również mężczyźni pozostający nie tylko w stosunkach pozamałżeńskich z innymi kobietami, ale także dopuszczający się stosunków z własnymi córkami (również nieślubnymi), a następnie wnuczkami ${ }^{25}$.

Nastoletni chłopiec wcześnie nawiązywał pierwsze kontakty z dziewczętami, jednak zanim związał się węzłem małżeńskim z jedną z nich, musiał jeszcze odbyć służbę wojskową. Dopiero po spełnieniu tego obowiązku młody mężczyzna zwany parobkiem lub łegyniem, mając około 24 lat, zakładał własną rodzinę ${ }^{26}$. Nie brakowało również mężczyzn żeniących się dopiero w wieku 30-35 lat z kobietami mającymi 25-30 lat, jednak znacznie częściej na Huculszczyźnie można było spotkać żony w bardzo młodym wieku. Przyczyną tak dużych rozbieżności w wieku nowożeńców mógł być w pewnej mierze fakt, że nawet rodzice nie pamiętali dokładnie roku narodzin swoich dzieci i nie potrafili określić, kiedy osiągały one pełnoletniośćc ${ }^{27}$.

Zawieranie związków małżeńskich nie było na Huculszczyźnie koniecznością. Wśród mieszkańców górskich miejscowości spotykano zarówno niezamężne samotne kobiety, jak i mężczyzn, którzy prowadzenie gospodarstwa domowego powierzali wynajętym gospodyniom. Istniały także związki nieślubne, w których mężczyzna i kobieta wzajemnie przysięgali sobie wierność i oddanie przy grudce soli i dwóch zapalonych świeczkach ${ }^{28}$.

Najczęściej jednak dorastający młodzi ludzie, przeżywający fascynację płcią przeciwną, zaczynali także myśleć o tradycyjnym ożenku. Panujące na Huculszczyźnie zwyczaje wskazywały na znaczący udział mężczyzn przy tworzeniu nowej rodziny i ich dominującą rolę w tradycyjnej hierarchii społecznej. Oficjalne działania, mające doprowadzić do zawarcia małżeństwa, podejmował zazwyczaj łegyń czyli kawaler. Upatrzywszy dziewczynę, z którą chciałby się ożenić, wybierał dwóch swatów spośród krewnych lub znajomych, a następnie razem z nimi udawał się wieczorem do domu wybranki.

${ }^{24}$ M. Orłowicz, Ilustrowany przewodnik po Galicyi, Lwów 1919, s. 200.

${ }_{25}$ Р. Ф. Кайндль, Гуиули, s.15-16; sytuację taką przeniósł również do literatury współczesny ukraiński pisarz Taras Prochaśko w powieści Niezwykli, Wołowiec 2005.

${ }^{26}$ Р. Ф. Кайндль, Гуиули, s. 19. Dziewczęta wychodziły za mąż, mając często lat 16.

27 Ibidem, s. 20.

${ }^{28}$ Ibidem, s. 26. 
Syn mógł liczyć na ożenek z dziewczyną, którą sobie upodobał, pod warunkiem zaakceptowania jego wyboru przez rodziców. Swataniem i ustalaniem z rodzicami dziewczyny warunków mariażu zajmował się ojciec chłopaka lub wybrany przez ojca swat. Przyszłość młodych zależała więc od umów i ustaleń, jakie czynili między sobą wymienieni mężczyźni ${ }^{29}$. Ojciec nie mógł ożenić syna ani wydać córki za mąż, jeśli dziecko zdecydowanie sprzeciwiało się temu zamiarowi. Przymuszanie do zawarcia małżeństwa podlegało karze. Do mężczyzn należało również załatwienie wszelkich formalności związanych ze ślubem w kościele. Do księdza udawał się ojciec kawalera lub matka z opiekunem (gdy ojca nie było), ojciec młodej lub matka (jeśli nie było ojca), narzeczeni oraz starosta. Ustaleń dotyczących ślubu dokonywał starosta lub jeden $\mathrm{z}$ ojców ${ }^{30}$. W trakcie wesela, gdy młodzi byli razem, następowało symboliczne wykupienie młodej z rąk starosty przez pana młodego. Dopiero wówczas mógł on zasiąść obok żony, odsłonić jej twarz i rozpocząć główną wieczerzę weselną ${ }^{31}$.

Wedle tradycji huculskiej żona musiała być podległa mężowi. Zewnętrznym przejawem podkreślającym to prawo był między innymi fakt, że idąc drogą kobieta zawsze przynajmniej jeden krok pozostawała za mężczyzną. To on, pan i władca, kroczył na przedzie. Kobieta również dźwigała większe ciężary. Pokonując nawet znaczne odległości, konno jechał zawsze mąż, podczas gdy żona szła obok pieszo. Mężczyzna również jako pierwszy przekraczał drzwi każdego domu ${ }^{32}$. Mężowie odpowiadali za postępowanie swoich żon. Ponosili zatem kary za niewłaściwe ich zachowanie, ponieważ w ich gestii leżało zapobieganie łamaniu prawa przez żony ${ }^{33}$.

O żonie Hucuł mówił często w sposób lekceważący, nazywając ją „babą"34. Po śmierci żony używał natomiast zwrotu „погибла”, którym określano śmierć bydła. Do normalnych zachowań należało bicie żon, a słuszność tych poczynań potwierdzały powiedzenia np. jak chcesz mieć dobra żonę, to musisz walić ja jak drewno, żona bije językiem, a ty jej i pięściami nie pokonasz. Nie do końca chyba jednak Huculi przejawiali w stosunku do swoich kobiet tak drastyczne podejście, skoro powiadali również płać swoje podatki i kochaj żonę swoją ${ }^{35}$.

Lekceważący stosunek do kobiet huculscy mężowie łączyli z chorobliwą wręcz zazdrością i zaborczością. Awantury i rękoczyny wywoływały nawet najmniejsze kontakty żon z innymi mężczyznami. Każda okazja była dobrym pretekstem do przypomnienia żonie o swojej wyższości i panowaniu nad nią. W takiej atmosferze nie można było budować poprawnych związków małżeńskich, a przejawy niewierności bardzo szybko pojawiały się u obu stron. Mężczyzna wiązał się z inną kobietą, by podkreślać swoją niezależność i wyższość nad żoną, ona natomiast szukała ciepła, przychylności i miłości

\footnotetext{
${ }^{29}$ L. Wajgiel, O Hucułach. Zarys etnograficzny, b/d, s. 15.

30 Ibidem, s. 17.

31 Ibidem, s. 20.

32 Р. Ф. Кайндль, Гуцули, s. 27.

${ }_{33}$ Ю. Гошко, Звичаєве право..., s. 240.

34 Р. Ф. Кайндль, Гуиули, s. 29.

35 Ibidem, s. 27.
} 
u innego mężczyzny, który będąc kochankiem, nie musiał okazywać kobiecie swojej siły fizycznej, stosując rękoczyny. Z dzisiejszego punktu widzenia dziwić może nieco mentalność ówczesnych Hucułek, które doznawszy tylu upokorzeń ze strony mężów, darzyły nadal zaufaniem innych mężczyzn. Brak pozytywnych więzi pomiędzy małżonkami miał ogromny wpływ na demoralizację społeczeństwa. Mówiąc o tym zjawisku, dodać należy jeszcze, że Hucuł nie miał pretensji do żony o zdradę wówczas, gdy związywała się ona z zamożnym mężczyzną, ponieważ taki związek traktował jako dodatkowe źródło dochodów ${ }^{36}$. Jeśli korzyści ze zdrady żony nie było, bądź mąż był bardziej porywczy, to dochodziło nawet do wyrzucenia małżonki z domu. Najczęściej jej miejsce w krótkim czasie zajmowała inna kobieta, z którą Hucuł był już wcześniej związany. Porzucona kobieta wracała do swojego rodzinnego domu lub wiązała się z innym mężczyzną. Na porzucenie mężów zdobywały się również kobiety. Czasem także krewki Hucuł utrzymywał kilka żon. Teoretycznie usprawiedliwiano rozpad małżeństwa w przypadkach nastawania jednego z partnerów na życie drugiego. Zwyczajowo popierano i akceptowano także wyrzucenie z domu żony zbyt kłótliwej lub niegospodarnej ${ }^{37}$.

Za sprawą prawa cerkiewnego kobiety uzyskały przywilej ubiegania się o rozwód. Przyczynami, dla których żony mogły wystąpić z oskarżeniem przeciw mężom było działanie zniesławiające ich cześć, spiskowanie męża przeciwko państwu lub ukrywanie przestępców i zdrajców, pomówienie żony o zdradę bez poświadczonych dowodów, sprowadzenie kochanki do domu lub udowodniony związek męża z inną kobietą ${ }^{38}$. Sądy faworyzowały jednak mężczyzn pod względem prawnym, ponieważ za dopuszczenie się zdrady mężów karano jedynie drobnymi grzywnami, natomiast mężatki podejrzane o zdradę stawiano przed sądem, gdzie biciem wymuszano na nich przyznanie się do winy $^{39}$.

W przypadku rozstania małżonków, dzieci przebywały z rodzicem, który pozostawał $\mathrm{w}$ domu. Biorąc zatem pod uwagę fakt, że nowożeńcy zamieszkiwali w domu pana młodego, opieka nad dziećmi przechodziła na ojca.

Po bezdzietnej śmierci żony lub po jej oddaleniu mąż był zobowiązany do zwrotu teściom (w pierwszym przypadku), bądź żonie wszystkiego co wniosła w wianie, wstępując $\mathrm{w}$ związek małżeński. Z chwilą śmierci jednego z małżonków cały majątek przechodził na drugiego, natomiast gdy oboje umierali nie pozostawiwszy spadkobierców ani testamentu, wówczas to co posiadali, dzielono między rodziców obojga. W świetle obowiązujących w kraju przepisów, córki nie miały w ogóle prawa do ojcowizny po śmierci rodziców. Cały majątek po rodzicach dziedziczyli zatem synowie, co również stawiało mężczyzn na pozycji uprzywilejowanej ${ }^{40}$. Zdecydowanie należy więc stwierdzić, że w strukturze rodzinnej przewagę zawsze miały linie męskie i ich męscy członkowie.

\footnotetext{
36 Ibidem, s. 28.

37 Ibidem, s. 29.

${ }^{38}$ Ю. Гошко, Звичаєве право..., s. 257.

39 Ibidem, s. 265.

40 Р. Ф. Кайндль, Гуцули, s. 29.
} 
Dożywszy 60 roku życia, mężczyzna dołączał do grona szanowanych starców, którzy swoją powagą decydowali o ważnych sprawach wsi (np. odmierzanie pól, osądzanie winnych itp. $)^{41}$. Mężczyźni choć świadomi swojej siły i zręczności nie unikali wiary w liczne przesądy towarzyszące wykonywanym przez nich zajęciom. Hucuł chcący skutecznie upolować niedźwiedzia, musiał poświęcić w cerkwi kulę, którą zamierzał strzelać. Jeśli natomiast idącemu na polowanie drogę przeszła kobieta $\mathrm{z}$ pustymi rękami, miało to przepowiadać niepowodzenie, gdy natomiast kobieta niosła duży ciężar - sukces łowiecki był zapewniony ${ }^{42}$. Często wróżyli i przepowiadali odpowiednie rzeczy, obserwując naturę ${ }^{43}$.

Analizując stosunki panujące w rodzinach huculskich, należy stwierdzić, że silna pozycja mężczyzny nie szła w parze z zapewnieniem stabilizacji i spokojnego życia w zgodzie z ogólnie przyjętymi zasadami moralnymi. Rodzice często uwzględniali zdanie dzieci i przychylali się do ich wyboru dokonywanego pod wpływem młodzieńczych uczuć, co nie wpływało pozytywnie na trwałość związków. Z drugiej strony nie brakowało również małżeństw zawieranych wyłącznie z wyrachowania, przy udziale pośredników, wyłącznie dla pozyskania posagu i majątku. Czynniki te powodowały powszechny na Huculszczyźnie brak przykładnego pożycia małżeńskiego. Każdy mąż miał kochankę „lubaskę”, a żona nie stroniła od kochanków „lubasów”. Wzajemne zdrady budziły podejrzliwość, nieufność, zazdrość i bijatyki, czemu oczywiście przyglądały się dzieci, powielając w przyszłości błędy rodziców. Patologia pożycia małżeńskiego i rodzinnego pogłębiała się również w skutek nadużywania alkoholu. Doprowadziło ono wielu zamożnych górali do utraty majątków, a coraz większa bieda zmuszała ich do podejmowania ciężkiej i nisko płatnej pracy w charakterze najemników. W rzeczywistości niewielu mężczyzn mogło stanowić dobry przykład do naśladowania dla swoich dzieci i w sposób właściwy wywiązywało się z zadań oraz ról społecznych.

${ }^{41}$ Ю. Гошко, Звичаєве право..., s. 238.

${ }^{42}$ L. Wajgiel, O Hucułach..., s. 22-23.

${ }_{43}$ Nadejście wiosny przewidywali np. spoglądając na księżyc przez jedwabną chustę i obliczając, ile ma dni do dnia dłuższego. Deszcz zwiastowało według nich np. wieczorne siadanie wron na dachach chałup, zimny wiatr od Czarnohory lub zasnucie ciemnymi chmurami szczytów gór, natomiast dobrą pogodę wydawanie odgłosów przez sowę lub cykający nocą świerszcz. Dobry urodzaj zapowiadała ładna pogoda na „Błahowiszczenie", w przeciwnym wypadku zboże miało w ogóle nie dojrzeć. Burza w Nowy Rok zwiastowała wojnę, piękna pogoda na św. Semena pomyślny cały rok, a duża ilość szyszek na świerkach zapowiadała motylicę u owiec. Ibidem, s. 25-26. 
